remarkably high in a no fault jurisdiction and strongly predictive of such occurences.

Doctors in many countries are discouraged from reporting medical errors, ${ }^{4}$ yet litigation in tort jurisdictions is becoming more common. ${ }^{5}$ In no fault jurisictions, the relatively high level of annotation in patient records that we found could provide a basis for more vigorous error reporting.

Contributors: PD designed the study and wrote the paper. RL-Y undertook the analysis, advised by AS. RB organised and oversaw the clinical assessments. SS provided technical advice. PD is guarantor.

Funding: Health Research Council of New Zealand.
Competing interests: None declared.

1 Davis P, Lay-Yee R, Briant R, Schug S, Scott A, Johnson S, et al. Adverse events in New Zealand public hospitals: principal findings from a national survey. Wellington: Ministry of Health, 2001. (Occasional paper No 3.) www.moh.govt.nz/moh.nsf (accessed 25 Nov 2002).

2 Gostin L. A public health approach to reducing error: medical malpractice as a barrier. JAMA 2000;283:1742.

3 Miller RS. An analysis and critique of the 1992 changes to New Zealand's accident compensation scheme. Maryland Law Rev 1993;52:1070-92.

4 Blendon RJ, Schoen C, Donelan K, Osborn R, DesRoches CM, Scoles K, et al. Physicians' views on quality of care: a five-country comparison. Health Aff 2001;20:233-43.

5 National Audit Office. Handling clinical negligence claims in England. London: Stationery Office, 2001

(Accepted 26 July 2002)

\title{
Review of deaths related to taking ecstasy, England and Wales, 1997-2000
}

Fabrizio Schifano, Adenekan Oyefeso, Lucy Webb, Mike Pollard, John Corkery, A Hamid Ghodse

National

Programme on

Substance Abuse

Deaths, Department

of Addictive

Behaviour and

Psychological

Medicine, St

George's Hospital

Medical School,

London SW17 0RE

Fabrizio Schifano

senior lecturer

Adenekan Oyefeso

senior lecturer

Lucy Webb

research nurse

Mike Pollard

database officer

John Corkery

homorary senio

research fellow

A Hamid Ghodse

chairman

Correspondence to:

F Schifano

f.schifano@

sghms.ac.uk

BMJ 2003;326:80-1
The lack of data about the lethal consequences of taking ecstasy has led to high profile reports of deaths in the media and also the idea that ecstasy is safe. The United Kingdom accounts for most of the ecstasy tabletsnormally containing methylenedioxymethamphetamine (MDMA) or 3,4-methylenedioxyamphetamine (MDA)-seized in the European Union. ${ }^{1}$ The rate of deaths related to taking ecstasy in people aged 15-24 during 1995 and 1996 in England was 18 and between 1995 and 1997 in Scotland was 11. ${ }^{2}$ The risk of using ecstasy varies between one death in 2000 first time users to one death in 50000 first time users. ${ }^{2}$

The National Programme on Substance Abuse Deaths was established after the Home Office Addicts Index closed. We report all the information recorded in the programme's database between 1 July 1997 and 30 June 2000 about deaths in England and Wales related to taking ecstasy.

\section{Participants, methods, and results}

Deaths are included on the database of the National Programme on Substance Abuse Deaths if one or more psychoactive substances are directly implicated in death, if the patient had a history of dependence on or misuse of psychoactive drugs, or if controlled drugs are found during necropsy. The response rate from coroners in England and Wales was high (about 95\%). ${ }^{3}$ We defined deaths related to ecstasy as a coroner's report including the text "ecstasy," "XTC," "MDMA," or "MDA."'

We identified 81 deaths related to taking ecstasy. Results of toxicological examination were made available in 75 cases; MDMA accounted for 68 (91\%), MDA for 7 (9\%), and opiates or opioids for $44(59 \%)$ of these cases. In $26(38 \%)$ cases, one or more drugs (mostly hypnotics or sedatives) had been prescribed to the deceased patient (table).

\section{Comment}

Most people who died from taking ecstasy were white employed men in their late 20 s, known to services as
Characteristics of 81 people whose death was related to ecstasy in England and Wales between 1 July 1997 and 30 June 2000. Values are numbers (percentages) unless stated otherwise

\begin{tabular}{|c|c|}
\hline Characteristic & Value \\
\hline \multicolumn{2}{|l|}{ Sex: } \\
\hline Male & $66(81)$ \\
\hline Female & $15(19)$ \\
\hline Age (years) & 27.2 (range 16-50) \\
\hline \multicolumn{2}{|l|}{ Ethnic origin: } \\
\hline White & $71(88)$ \\
\hline Black African & $3(4)$ \\
\hline Other & $7(9)$ \\
\hline \multicolumn{2}{|l|}{ Employment status: } \\
\hline Employed & $37(46)$ \\
\hline Unemployed & $36(44)$ \\
\hline Student & $8(10)$ \\
\hline Patients known as drug addicts to services or primary care & $46(57)$ \\
\hline \multicolumn{2}{|l|}{ Most common causes of death recorded by coroners: } \\
\hline Polysubstance poisoning & $50(62)$ \\
\hline Only MDMA poisoning & $6(7)$ \\
\hline Others" & $25(31)$ \\
\hline \multicolumn{2}{|l|}{ Place of death: } \\
\hline Private residence & $40(49)$ \\
\hline Hospital & $25(31)$ \\
\hline Pub or club & $2(2)$ \\
\hline Other & $14(17)$ \\
\hline \multicolumn{2}{|l|}{ Area of death: } \\
\hline London & $16(20)$ \\
\hline Southeast England & $10(12)$ \\
\hline Northeast England & $11(14)$ \\
\hline Northwest England & $14(17)$ \\
\hline Central England & $11(14)$ \\
\hline Other & $19(23)$ \\
\hline \multicolumn{2}{|l|}{ Month of death: } \\
\hline January & $10(12)$ \\
\hline July & $10(12)$ \\
\hline August & $8(10)$ \\
\hline Other & $53(65)$ \\
\hline \multicolumn{2}{|l|}{ Day of death: } \\
\hline Saturday & $16(20)$ \\
\hline Sunday & $29(36)$ \\
\hline Other & $36(44)$ \\
\hline
\end{tabular}

${ }^{\star}$ For example heart attack, trauma, drowning, or hyperpyrexia. 
drug addicts, and died at home. Typically, the deceased took several different (prescribed and non-prescribed) drugs with ecstasy; the large number of people who also took opiates seems surprising but confirms previous findings and may explain why a high proportion of the victims were known to services. ${ }^{4}$ People may have taken ecstasy with other drugs to modulate the effects-ecstasy had, at least, a facilitating role in causing death. A small proportion of people $(6 / 81$; $7 \%$ ) died after taking only ecstasy-a previously doubted possibility. ${ }^{5}$ Toxicological tests could detect all drugs that had been taken in the 2-3 days before death and gave only limited information about which drugs had been taken on the last occasion. Deaths related to ecstasy occurred in two clusters (urban industrial areas in southeast and northern England); people died mostly at party times (weekends, summer, and at New Year).

Information about the incidence of taking ecstasy and other drugs and amounts taken is unfortunately lacking; the database of the National Programme on Substance Abuse Deaths (which is being extended to Northern Ireland and Scotland) will collect more information in future-for example, the concentration of individual drugs in tissues-to obtain a better understanding of the role of other drugs in deaths related to taking ecstasy.

Contributors: FS wrote the manuscript and coordinated the study. AO, LW, MP, and JC collected data and interpreted the results. AHG participated in interpreting the results. FS is guarantor.

Funding: No additional funding.

Competing interests: None declared.

1 European Monitoring Centre for Drug and Drug Addiction. Annua report on the state of drugs problems in the European Union. Lisbon: EMCDDA, 2001.

2 Gore SM. Fatal uncertainty: death-rate from use of ecstasy or heroin. Lancet 1999:354:1265-6.

3 Ghodse AH, Oyefeso A, Webb L, Schifano F, Pollard M, Jambert-Gray R, et al. Drug-related deaths as reported by coroners in England and Wales. London: European Centre for Addiction Studies, 2002. (Annual review 2001 and np-SAD surveillance report No 9.)

4 Schifano F. Potential human neurotoxicity of MDMA ("ecstasy"): subjective self-reports, evidence from an Italian drug addiction centre and clinical case studies. Neuropsychobiology 2000;42:25-33.

5 Giroud C, Augsburger M, Sadeghipour F, Varesio E, Veuthey JL, Rivier L. Ecstasy: the status in French-speaking Switzerland: composition of seized Ecstasy: the status in French-speaking Switzerland: composition of seized
drugs, analysis of biological specimens and short review of its pharmacodrugs, analysis of biological specimens and short review of its pharma
logical action and toxicity. Schweiz Rundsch Med Prax 1997;86:510-23. (Accepted 21 June 2002)

\title{
Recent changes in lung cancer incidence for south Asians: a population based register study
}

\author{
Lucy K Smith, Michael D Peake, Johannes L Botha
}

In Britain the incidence of lung cancer among south Asians (Indian, Pakistani, and Bangladeshi) is much lower than in the rest of the population. ${ }^{1}$ In the UK south Asian population, however, it is the commonest cancer for men and the second commonest for women. ${ }^{2}$ Little has been reported on lung cancer trends among south Asians in Britain. We explored trends in lung cancer incidence from 1990 to 1999 in Leicester (22\% of residents classified as south Asian in 1991 census).

\section{Participants, methods, and results}

We identified cases of lung cancer diagnosed in Leicester residents between 1 January 1990 and 31 December 1999 from the Trent Cancer Registry. Ethnicity data were not available for all patients, so we used software assessing forename and surname to classify patients as south Asian or non-south Asian, ${ }^{3}$ with visual inspection of the data to increase accuracy. We assessed deprivation using the Townsend index. The local research ethics committee approved the study.

Population estimates at the level of electoral wards from the 1991 census (categorised by sex, ethnicity, and 5 year age bands) were aggregated by deprivation tertile to calculate lung cancer incidence. We investigated variation in incidence by ethnicity, deprivation, age, and year of diagnosis and any interactions between them using Poisson regression separately for men and women. We calculated the interaction between period of diagnosis (1990-4 or 1995-9) and ethnicity to compare trends over time.

Of the 1902 patients with lung cancer identified, 76 were classified as south Asian (4\%). South Asians were slightly younger than non-south Asians (median age $70.3 v 72.1$ years). After adjusting for differences in age and deprivation, we found lung cancer rates were lower for south Asians than non-south Asians (incidence ratio for men 0.41 (95\% confidence interval 0.31 to $0.54)$, for women 0.32 ( 0.20 to 0.50$)$ ).

The adjusted incidence increased over time for south Asian men but decreased for non-south Asian men $(\mathrm{P}=0.038)$, with an increase in risk of $43 \%$ for south Asian men (incidence ratio for 1990-4 v 1995-9 1.43 (0.84 to 2.44)) and a decrease of $19 \%$ for non-south Asian men (0.81 (0.72 to 0.91)). For non-south Asian men, the decrease in incidence occurred in those from more deprived areas, where lung cancer incidence was higher (see figure). There was no evidence of a trend with deprivation over time for south Asian men.

Patterns for women were different, with slight increases in lung cancer incidence over time for both south Asians and non-south Asians and no evidence of differing patterns over time $(\mathrm{P}=0.489)$. South Asian women had a $50 \%$ increase in risk (1.50 (0.61 to 3.67)), while the increase in risk for non-south Asians was 9\% (1.09 (0.93 to 1.28)). The changes in incidence over time were similar for all levels of deprivation (see figure).
Department of Epidemiology and Public Health, University of Leicester, Leicester LE1 6TP Lucy K Smith research fellow

Glenfield Hospital, Leicester LE3 9QP Michael D Peake consultant physician and lead clinician for lung cancer

Trent Cancer Registry, Weston Park Hospital, Sheffield S10 2SJ Johannes L Botha director

Correspondence to: L K Smith lks1@le.ac.uk

BMJ 2003;326:81-2 